\title{
Proficiency Perceptions and Attitudes of Pre-Service Teachers on İnformation and Communication Technologies
}

\author{
İlhami Arseven ${ }^{1}$, Ahmet Turan Orhan ${ }^{1} \&$ Ayla Arseven ${ }^{1}$ \\ ${ }^{1}$ Faculty of Education, Sivas Cumhuriyet University, Sivas, Turkey \\ Correspondence: Ayla Arseven, Faculty of Education, Sivas Cumhuriyet University, Sivas, Turkey. Tel: \\ 346-219-1010-4657. E-mail: aylaarseven2004@yahoo.com
}

Received: August 29, 2018

doi:10.5539/ies.v12n1p24
Accepted: September 30, $2018 \quad$ Online Published: December 28, 2018

URL: https://doi.org/10.5539/ies.v12n1p24

\begin{abstract}
The aim of this study is to examine teacher candidates' perceptions of their own proficiency in using information and communication technologies and their attitudes towards information and communication technologies in terms of gender, major, internet usage frequency and computer ownership. The study group consists of 336 teacher candidates, 98 male $(29 \%)$ and 238 female $(71 \%)$ senior students, in different departments at Cumhuriyet University Faculty of Education during the 2017-2018 academic year. The "Proficiency Perception Scale for Using Information and Communication Technologies" and "The Attitude Scale for Information and Communication Technologies" developed by different researchers were administered to the candidate teachers. As a result of the findings obtained from the research, there was no significant difference between proficiency levels of the teacher candidates regarding the use of information and communication technologies. Besides, there was not significant difference between the means of attitude towards information and communication technologies in terms of majors and the internet usage frequency, and between the mean proficiency perception scores of using information and communication technologies with regard to gender. It was ascertained that there was a slightly meaningful difference between the attitudes scores for information and communication technologies in favor of males in terms of gender, and as to computer ownership, there was a low level of difference between both attitude and perception scores in favor of computer owners. The findings are discussed within the scope of literature.
\end{abstract}

Keywords: prospective teachers, information and communication technologies, competency perception, attitude

\section{Introduction}

While the possibilities of information conservation, sharing, transferring and accessing were extremely restricted until about a century ago, all these things have become much easier nowadays thanks to technological developments. Until recently, books were the most common means through which information was recorded and shared, but now electronic books can be easily accessed on the internet. While instructional activities were only carried out in schools and classes until a short time ago, today, with web-based distance education systems, teaching activities can be done at home and work without space limitation. Today, an academician can have access to a scholarly article by another college professor read and make a scientific discussion on the article with its author on the web from the other side of the world. All these developments have radically altered the basic philosophy, content, methods, and tools of education and more specifically teaching, and differentiated teacher and student roles in learning and teaching. While the teacher assumed authority and holder of information about his field and transferred this information, $\mathrm{s} /$ he has changed his/her role as a guide to access and share information by leaving the role of information transporting authority, as information and communication technologies have entered daily life and information has become easily accessible to everyone. Additionally, students have taken active learners who obtain information from different sources, researches and interpret it and share this information in the class environment. In short, learners construct knowledge in their mind leaving the role of a passive receiver of information. This transformation has obliged teachers to have not only teaching or field knowledge and skills but also the knowledge and skills to use information and communication technologies and to be able to integrate them with instructional activities.

\subsection{Information and Communication Technologies and Their Role in Education}

According to Ceyhun and Çağlayan (1997), information and communication technologies (ICTs) are the collection of technologies which enable to collect, process, store information and transmit this information to anywhere when 
necessary, or access from any place by means of electronic techniques automatically (Cited in, Yirci \& Aydoğar, 2017). Technologies that allow for the creation, conservation, use, sharing and transfer of information are called information and communication technologies (Firat \& Özden, 2015). According to Pelgrum and Law (2003), by the end of the 1980s, the term computer was replaced with the term "information technology" as an indication of the transition from information processing technology to information storage and retrieval capacity. The concept of "information and communication technology" emerged when electronic mail began to enter the public domain in 1992. In addition to computers, which have many types such as desktop computers, laptop computers, tablet computers and so on, this concept today includes many different types of technological devices. Many technologies like televisions, radios, satellite systems, fixed and mobile telephones, fax machines, CD-ROMs, internet etc. are called information and communication technologies (Sanyal, 2001).

The use of information and communication technologies is increasing and becoming widespread. Although this increase and expansion differ from country to country, each country is endeavoring to expand the use of information and communication technologies to keep up with conditions becoming more competitive. Information and communication technologies are widely used in education as well as in many other areas like industry, commerce, transportation and so on.

The introduction of information and communication technologies into the field of education has constituted fundamental changes in education systems. The interaction element provided by information and communication technologies has made learning and teaching activities much more interesting and meaningful. With the Internet becoming an integral part of daily life, students do no longer have to rely on teachers as sole information providers, and the students have the opportunity to access the information anytime and anywhere with the Internet technology. They can also communicate with each other via internet-based social networks (Umar and Jalil, 2012).

Information and communication technologies enable rapid access to information, and the conservation, sharing, and transfer of information have become much easier. With sharing of information, the amount of newly produced information is rapidly increasing; technologies produced with innovative information facilitate human life (Polat and Odabaş, 2008). The role of education systems in keeping up this fast-paced change and transformation is gaining importance. It is necessary for individuals to have simple knowledge and skills necessary to use information and communication technologies to be a part of the society in which information and technology dominate and to develop society. Undoubtedly, it is the basic aim of education to gain these knowledge and skills. To achieve this purpose, it is necessary to establish the educational technology infrastructure of the schools, faculties and classes which constitute the basis of the formal education system, to create the possibilities for students to reach these technologies easily, and to develop teaching programs which will redound knowledge and skills about using information and communication technologies. Also, knowledge and skills of using information and communication technologies effectively in teaching should be considered as a fundamental competency in teacher education.

According to Jamiason et al. (2013), integration of information and communication technologies in education often means technology-based teaching and learning processes that are closely related to the use of instructional technologies in schools. ICT integration is of vital importance, especially for schools, as students are familiar with technology and learn better in technology-based settings. The use of technology in education leads to effective learning with the help and support of the ICT applications, items and components (Cited in, Ghavifekr and Rosdy, 2015). Information and communication technologies offer a variety of opportunities for students and teachers in the teaching-learning process. The integration of opportunities such as lecture software, computer-assisted instruction, Internet-based instruction, distance education, video conferencing and the Internet into teaching creates a rich learning environment (Tuti, 2005). However, as mentioned before, schools need to have the necessary information and communication technology equipment to actualize all these.

The European Commission has made a school survey study in 27 countries, including Turkey, about the status of information and communication technology in education in 2011-2012, and has published the final report of the study in 2013. As a result of the study, the number of students per computers, Internet-connected laptops and interactive smart boards in 4th grade in primary school, 8th grade in secondary school, 11th grade in common and vocational high school in Turkey is above the average of the European Union (European Commission, 2013). The Commission conducted a new study in 2017 to track the developments in this report on a country-by-country basis but has not yet published its results. Since 2011 when the first survey was done, main investments and projects for the development of information and communication technology infrastructure in schools in Turkey have been made. The FATIH project is the most important one among all. The project seeks to equip each classroom with smart board and wired / wireless internet connection, and each teacher and student with tablet computer and e-mail account. The FATIH project aims to provide the equipment of classrooms, to deliver broadband internet to all 
classrooms, to provide e-content of the classes, to integrate teachers into information technologies and to use information technologies effectively in teaching programs (MEB, 2018).

It is also important that our teachers have the knowledge and skills to use information and communication technologies as well as the infrastructure of information and communication technology in schools. For information and communication technologies to be used appropriately and efficiently in schools, it is crucial for teachers to acquire relevant competencies via pre-service and in-service training. "Effective use of information and communication technologies in the process of learning and teaching" under the heading "Basic Ability to Manage Learning and Teaching Process" among the "General Competencies of Teaching Profession" published by Ministry of National Education (2017) is emphasized as a competency.

The International Association of Educational Technologies (ISTE) has developed a set of standards for teacher training programs for teachers specializing in information and communication technologies. These standards were adopted by the American Teacher Education National Accreditation Council and are still being used to evaluate teacher training programs. Accordingly, all classroom teachers should meet these standards and performance indicators related to information and communication technologies. Standard and performance indicators were collected in four main categories (UNESCO, 2002). The first is technological concepts and applications. In this regard, each teacher is expected to understand concepts, display knowledge and skills related to technology by behavior and continuously improve the knowledge and skills related to technology to keep pace with current and emerging technologies. The second basic standard is planning and designing learning environments and experiences. Within the scope of this heading, each teacher is supposed to design learning opportunities to apply technology-based instructional strategies according to student needs using the results of research and technology-related research, to identify the sources of technology and evaluate technology resources in terms of teaching appropriateness. Additionally, the teacher is expected to plan these resources for use in learning activities and to plan strategies to guide learning in technology-enhanced learning environments. The third standard is teaching, learning and program. On this matter, each teacher is required to use technology to support student-centered teaching strategies appropriate for the different needs of the students and improve students' high-level skills and creativity. Teachers also need to manage learning activities in a technology-supported environment. The final main title of the standards is the assessment and evaluation in which each teacher is expected to use technology to assess students' learning situation, to maximize learning by collecting, analyzing, interpreting the results and developing suitable teaching practices. Various evaluation methods to determine appropriate technology resources for students in learning, communication and productivity should also be applied by teachers (UNESCO, 2002).

In order for information and communication technologies to be used effectively in the learning-teaching process, it is evaluated that the level of proficiency perception of teachers using information and communication technologies and their attitudes towards information and communication technologies should be increased positively via training and raising competence of teachers in information and communication technologies. The concept of competence or self-efficacy constitutes an important part of people's motivation and behavior. According to Bandura (1977), self-efficacy is one's belief in his/her competence in planning and carrying out the forms of movement that one needs to manage future situations. Bandura's (1982) self-efficacy theory is based on the belief that people's beliefs about how successful they can shape a part of their performance and motivation (cited in Arseven, 2016). According to Özbey (2010), the attitude towards a subject, an object, or event develops before behavior and is also the pioneer of behavior or performance against them. It occurs before behavior and leads to the emergence of behavior or performance (cited in Kalkan, 2011). It is possible to say that our competency concerning something and attitude directly affects our behavior and performance on that thing. Therefore, as much as the knowledge and skills related to information and communication technologies, the competency perception and attitudes of teachers to use them are also very important.

When it comes to literature, there are several studies related to the attitudes of teachers and prospective teachers, both in their competence to use information and communication technologies and their attitudes. Erdemir, Bakirc1, and Eyduran (2009) investigated the confidence of teacher candidates to use technology in education and administered likert type technology attitude scale to 325 teacher candidates. As a result of the study, it was determined that prospective teachers feel inadequate in using the internet and computer for instructional purposes and preparing complex and multi-purpose teaching devices. In the research conducted by Şad and Nalçac1 (2015), the perceptions of prospective teachers about using information and communication technologies were examined regarding various variables. The scale developed for this purpose was administrated to 409 teacher candidates. At the end of the study, it was found that the candidate teachers regard themselves capable of using ICT in general and the teacher candidates who own computers see themselves more capable than those who do not. Sayginer (2016) 
examined 252 teacher candidates' computer and technology proficiency perceptions by administrating the computer proficiency scale and technology perception scale. At the end of the research, it was found that the areas where the teacher candidates are the weakest in terms of computer competence are preparing databases and web pages, and the computer competencies of males are higher than females. In addition, it was determined that the computer competencies of the individuals with computer and internet access are higher than those who do not have computer skills. Finally, it was found that Science and English teacher candidates' perceptions towards technology are higher than those who have studied in other departments.

In the study conducted by Yilmaz (2016), the attitudes of the elementary school teachers were examined according to various variables and attitude scale was administered to 360 elementary school teachers. At the end of the study, it was determined that teachers who had teaching experience between 5 and 9 years had higher attitudes than teachers who had 20 years or more teaching experience. Yirci and Aydoğar (2017) examined the attitudes of university students towards information and communication technologies in terms of various variables and applied attitude scale to 352 university students. When the attitude means of the university students on information and communication technologies were examined with regard to gender, faculty, time spent on ICT, males had higher scores than females and this difference was significant, but there was no statistically significant difference in terms of age variable.

In the survey conducted by Kubiatko (2010), the attitudes of university students towards ICT were examined by administrating attitude scale to 316 university students. At the end of the research, male students and students living in the city were found to have higher attitudes than the other students in the study. In a study conducted by Mai (2015), the attitudes of Science Teachers towards ICT were examined and attitude scale related to the subject was applied to 67 teachers. Science teachers were found to have a positive attitude towards ICT. Also, it was found that their attitudes towards were able to be predicted from their perception and self-efficacy towards ICT. In a study by Scherer and Siddiq (2015), three sub-dimensions of self-sufficiency related to using information and communication technologies were found. These sub-dimensions were self-efficacy in fundamental practice skills, self-efficacy in advanced practice and cooperation, and self-efficacy in using computers for instructional purposes. In the study, self-efficacy scale was applied to 1208 middle school teachers and male teachers' self-efficacy level in basic and advanced practice skills was found significantly higher than that of female teachers. In the research carried out by Gles and Kent (2016), the self-efficacy of the teacher candidates on integrating the technology into education was examined, and a Likert type proficiency scale was applied to 28 teacher candidates. It was found as a result of the research that $93 \%$ of the teacher candidates included the ICT to their courses and $68 \%$ have a high level of confidence in choosing and using the appropriate technology in the teaching process.

In the study conducted by Fanai and Chhangte (2016), the attitudes of middle school teachers towards ICT were examined regarding various variables. It was found that teachers generally have positive attitudes towards ICT, there is no meaningful difference between senior and junior teachers in attitudes towards ICT, and education adequacy on ICT does not affect attitudes towards ICT. In a survey conducted by Albert (2016), high school teachers' attitudes towards ICT use in the learning-teaching process were examined. As a result, it was found that teachers in general have neutral attitude and that there is a significant difference in the use of technology between male and female teachers.

Taking into account all these surveys, they have revealed very different both positive and negative results regarding various variables related to teachers' or teacher candidates' perceptions of competence in using ICT and their attitudes towards ICT.

In this study, the perception of competence related to the use of ICT and the attitude toward ICT, which were taken separately in the related studies, were examined together. The findings and results are also discussed within the scope of literature.

\subsection{Purpose of the Study}

The aim of this study is to determine the level of proficiency perceptions of teacher candidates regarding the use of information and communication technologies and attitudes towards information and communication technologies in terms of gender, major, the frequency of internet use and computer ownership. It is thought that this study, in which teacher candidates' perceptions of proficiency in information and communication technologies, and their attitudes towards information and communication technologies, can be a source of data for the Ministry of National Education, administrators of universities of education faculties and researchers interested in the subject.

\subsection{Research Questions}

1) Do the perceptions of teacher candidates in using information and communication technologies and their 
attitudes towards information and communication technologies differ by gender?

2) Do the teacher candidates' perceptions of competence in using information and communication technologies differ by the frequency of internet usage?

3) Do the attitudes of teacher candidates towards information and communication technologies differ by the frequency of internet use?

4) Do the prospective teachers' perceptions of competence in using information and communication technologies differ by majors?

5) Do the teacher candidates differ in their attitudes towards information and communication technologies by majors?

6) Do the prospective teachers' perceptions of competence in using information and communication technologies and attitudes towards information and communication technologies differ by computer ownership?

\section{Methodology}

In this section, the study group, data collection tools, and analysis of data headings are presented.

\subsection{Study Group}

The study group consists of a total of senior 336 teacher candidates attending Cumhuriyet University Faculty of Education. 238 of the prospective teachers are female (71\%) and 98 are male $(29 \%)$. Descriptive information related to the research group is given in Table 1.

Table 1. Descriptive information on teacher candidates in the research group

\begin{tabular}{lccccccc}
\hline \multirow{2}{*}{ Number of Students } & & \multicolumn{4}{c}{ Gender } \\
\cline { 5 - 8 } & & & \multicolumn{3}{c}{ Male } & \multicolumn{3}{c}{ Female } \\
\hline Program & $\mathrm{f}$ & $\%$ & $\mathrm{f}$ & $\%$ & $\mathrm{f}$ & $\%$ \\
Science Education & 70 & 20.8 & 18 & 18.3 & 52 & 21.9 \\
Mathematics Education & 41 & 12.2 & 13 & 13.2 & 28 & 11.8 \\
Preschool Education & 44 & 13.1 & 7 & 7.1 & 37 & 15.5 \\
Psychological Counseling and Guidance & 54 & 16.1 & 18 & 18.3 & 36 & 15.1 \\
Elementary Education & 38 & 11.3 & 12 & 12.2 & 26 & 10.9 \\
Social Sciences Education & 42 & 12.5 & 16 & 16.3 & 26 & 10.9 \\
Turkish Language Education & 47 & 14 & 14 & 14.2 & 33 & 13.8 \\
Total & 336 & 100 & 98 & 100 & 238 & 100 \\
\hline
\end{tabular}

\subsection{Data Collection Tools}

In this study, "Proficiency Perception Scale on Using Information and Communication Technologies" (PPSUICT) developed by Şad and Nalçac1 (2015) was used to determine the proficiency perceptions of prospective teachers in using information and communication technologies. The "Attitude Scale Toward Information and Communication Technologies" developed by Günbatar (2014) was used to determine another variant of the study, the attitudes of prospective teachers towards information and communication technologies.

The scale developed by Şad and Nalçacı (2015), Proficiency Perception Scale on Using Information and Communication Technologies (PPSUICT), consists of 30 items. It was developed within the framework of the performance indicators defined by the Ministry of Education's general qualifications for teaching profession (MEB 2006). The items of the scale are rated as (5) "highly qualified" and (1) "highly inadequate". The internal consistency coefficient of the Cronbach Alpha scale was .96. In this study, The Cronbach Alpha internal consistency coefficient calculated on the collected data was found to be .96 . Thus, it can be argued that the reliability levels of scale items are sufficient.

The Attitude Scale Toward Information and Communication Technologies (ASTICT), developed by Günbatar (2014), consists of 23 items. The scale items are rated on the scale (5) "I strongly agree" and (1) "I absolutely do not agree". The Cronbach Alpha internal consistency coefficient of the scale was .92. In this study, The Cronbach Alpha internal consistency coefficient calculated on the data collected was found to be .91. Hence, it can be said that the reliability levels of the scale items are sufficient. 
Personal Information Form: To collect personal information about teacher candidates, an information form including variables such as gender of students, majors, the frequency of internet use, computer ownership was developed and added to the beginning of the scale. After informing the prospective teachers about the purpose of the research, the scales were administered by the researchers during 2017-2018 academic year, at the end of the spring semester.

\subsection{Analysis of Data}

For the statistical analysis of the data, "PAST and SPSS 15" package programs were used. One-way PERMANOVA was used to determine whether the scores of teacher candidates' "Proficiency Perception Scale for Using Information and Communication Technologies" and "Attitude Scale for Information and Communication Technologies" differed by gender and computer ownership, and Kruskal-Wallis was used to determine whether they differed by majors and the frequency of internet use. The margin of error in the study was accepted as 0.05 .

\section{Findings and Interpretations}

In this section, the findings related to the research questions given in the introduction are discussed in the order of the research questions.

3.1 Findings on Whether Teacher Candidates' Perceptions of Proficiency in Using Information and Communication Technologies and Their Attitudes Towards Information and Communication Technologies Differ by Gender or not

To determine whether the Teacher Candidates' "Proficiency Perceptions of Using Information and Communication Technologies" and "Attitudes Towards Information and Communication Technologies" differ by gender, firstly, to determine the appropriate statistical test to be used, "Kolmogorov-Smirnov Normality Test" was used to test whether the scores from the scales were normally distributed in terms of gender. The results are given in Table 2.

Table 2. The table of normality of "PPSUICT" and "ASTICT" scores of teacher candidates in terms of genders

\begin{tabular}{ccccc}
\hline \multirow{2}{*}{ Gender } & \multicolumn{3}{c}{ Kolmogorov-Smirnov } \\
\cline { 3 - 5 } & & Statistic & df & Sig. \\
\hline \multirow{2}{*}{ PPSUICT scores } & female & .106 & 238 & .000 \\
& male & .108 & 98 & .006 \\
\hline \multirow{2}{*}{ ASTICT scores } & female & .095 & 238 & .000 \\
& male & .082 & 98 & .108 \\
\hline
\end{tabular}

The PPSUICT and ASTICT scores in all groups do not show normal distribution because of the girls' PPSUICT scores $(\mathrm{D}(238)=0.106, \mathrm{p}=0.000)$ and ASTICT scores $(\mathrm{D}(238)=0.095, \mathrm{p}=0.000)$ in Table 2. In this case, a one-way PERMANOVA test, a nonparametric test, was used to determine whether the prospective teacher candidates' perceptions of competence regarding ICT use and their attitudes towards ICT in terms of gender. Descriptive values of PPSUICT and ASTICT scores of teacher candidates are shown in Table 3, and the results of one-way PERMANOVA applied to PPSUICT and ASTICT scores in terms of gender are given in Table 4. In the PERMANOVA test, the line method was used as the permutation method and 9999 permutations were made. Bray-Curtis measurement was used as the distance measure. Analyzes were made using the "PAST" package program. According to Pasin, Ankaral, Cangür, and Sungur (2016), if the MANOVA method does not meet" normality assumption, PERMANOVA (Permutational Multivariate Analysis of Variance) which is a nonparametric multivariate analysis of variance is used. PERMANOVA uses the pseudo $F$ test statistic and uses permutation techniques while calculating $\mathrm{p}$-value. For this reason, this method does not require any distributional assumption. 
Table 3. Descriptive values of candidate teachers' PPSUICT and ASTICT scores in terms of gender

\begin{tabular}{cccccccc}
\hline & Gender & $\mathrm{N}$ & $\bar{x}$ & $\mathrm{ss}$ & $\mathrm{Z}$ & $\mathrm{p}$ & $\mathrm{r}$ \\
\hline \multirow{2}{*}{ PPSUICT } & Female & 238 & 3.71 & .61 & -1.423 & .155 & -0.08 \\
& Male & 98 & 3.68 & .59 & & & \\
\multirow{2}{*}{ ASTICT } & Female & 238 & 3.68 & .63 & -2.308 & .021 & -0.12 \\
& Male & 98 & 3.78 & .55 & & & \\
\hline
\end{tabular}

Table 4. Results of one-way PERMANOVA applied to PPSUICT and ASTICT scores of teacher candidates regarding gender

\begin{tabular}{ccccc}
\hline Independent Variable & Total Sum of Squares & Between Groups & $\mathrm{F}$ & $\mathrm{p}($ perm $)$ \\
\hline Gender & 2.007 & 1.999 & 1.44 & 0.250 \\
\hline
\end{tabular}

When Table 4 is examined, it is seen that there is no significant difference between perceptions of competence in using information and communication technologies and attitude scores towards information and communication technologies of teacher candite's of different genders $(p>.05)$. There is no significant difference between the PPSUICT score means according to the Mann Whitney U test result (Table 3), which was conducted to determine whether or not the mean of the PPSUICT and ASTICT scores of the prospective teachers' differ by gender ( $\mathrm{Z}=$ -1.423 and $\mathrm{p}=.155)(\mathrm{p}>.05)$. However, a significant difference was found between the ASTICT score points $(\mathrm{Z}=$ -2.308 and $\mathrm{p}=.021)(\mathrm{p}<.05)$.

In Table 3, when the ASTICT score means and standard deviation values of the female and male are examined, it is seen that the mean scores of the males are higher than the females'. On the other hand, the value of (r) was used to determine the magnitude of the effect of gender as an independent variable on ASTICT scores. The obtained $r$ value was interpreted in the direction of "d" index of Cohen (1988), which is one of the effect size indices. Cohen (1988) suggests that if the value of "d" is less than 0.2 , the effect size is weak and if the value of " $\mathrm{d}$ " is 0.5 , then the effect size is moderate. He states that if the value of "d" is greater than 0.8 , it means that the effect size can be defined strongly (cited in Kıliç, 2014, p. 45). Given the " $r$ " values ( $r=-0.08$ for PPSUICT score means and $r=$ -0.12 for ASTICT score means) obtained with regard to gender variation, it can be said that the gender variable has a weak influence on the attitudes of prospective teachers towards information and communication technologies.

\subsection{Findings on Whether the Teacher Candidates' Proficiency Perception Scores in Using Information and Communication Technologies Differ by Internet Usage Frequency}

To determine whether the Teacher Candidates' proficiency perception scores in ICT utilization differ by the frequency of internet use, firstly, to determine the appropriate statistical test to be used, "Kolmogorov-Smirnov Normality Test" was used to test whether the scores obtained from the scale were normally distributed in terms of the frequency of internet use. The results are given in Table 5.

Table 5. The table of normality of "PPSUICT" scores of teacher candidates in terms of the frequency of internet usage

\begin{tabular}{lcccc}
\hline \multirow{2}{*}{ Internet Usage Frequency } & \multicolumn{3}{c}{ Kolmogorov-Smirnov } \\
\cline { 3 - 5 } & Less than 1 hour per day & Statistic & df & Sig. \\
\hline \multirow{3}{*}{ PPSUICT } & 180 & 17 & .641 \\
& $1-2$ hours a day & .100 & 101 & .011 \\
& More than 2 hours a day & .106 & 218 & .000 \\
\hline
\end{tabular}

In Table 5, when the PPSUICT scores of the internet users who use internet more than 2 hours a day $(\mathrm{D}(218)=$ $0.106, p=0.000)$ and those who use internet for $1-2$ hours per day $(D(101)=0.100, p=0.011)$ are examined, PPSUICT scores do not show normal distribution in all groups. In this case, the Kruskal-Wallis test, a non-parametric test, was used to determine whether the candidate teachers' perceptions of competence regarding ICT use differ by the frequency of internet use. The results of this test are given in Table 6 . 
Table 6. Results of Kruskal-Wallis Test applied to "PPSUICT" scores of teacher candidates in terms of frequency of internet use

\begin{tabular}{ccccccc}
\hline & Groups & $\mathrm{N}$ & $\bar{x}_{(\mathrm{rank})}$ & $\chi^{2}$ & $\mathrm{sd}$ & $\mathrm{p}$ \\
\hline \multirow{3}{*}{ PPSUICT } & Less than 1 hour per day & 17 & 197.91 & & & \\
& $1-2$ hours a day & 101 & 168.82 & 1.698 & 2 & .428 \\
& More than 2 hours a day & 218 & 166.06 & & & \\
\hline
\end{tabular}

When Table 6 is examined, it is seen that there is no meaningful difference between the means of PPSUICT scores $\left(\chi^{2}=1.698\right.$ and $\left.\mathrm{p}>.05\right)$ of teacher candidates' and the frequency of internet use. Thus, the perceptions of competence of prospective teachers in using information and communication technologies do not differ by the frequency of internet use.

3.3 Findings on Whether Teacher Candidates' Attitudes Towards Information and Communication Technologies Differ by Internet Usage Frequency:

To determine whether the teacher candidates' attitude scores towards ICT differ by the frequency of internet use, at first, "Kolmogorov-Smirnov Normality Test" was used to test whether the scores of the scale are normally distributed in terms of the frequency of internet use to determine the appropriate statistical test to be used. The results are given in Table 7.

Table 7. Table of normality of "ASTICT" scores of teacher candidates in terms of the frequency of internet use

\begin{tabular}{lcccc}
\hline \multirow{2}{*}{ The frequency of internet use } & \multicolumn{3}{c}{ Kolmogorov-Smirnov } \\
\cline { 3 - 5 } & Less than 1 hour per day & .089 & 17 & .904 \\
\hline \multirow{3}{*}{ ASTICT } & $1-2$ hours a day & .100 & 101 & .002 \\
& More than 2 hours a day & .109 & 218 & .000 \\
\hline
\end{tabular}

Table 7 shows that when ASTICT scores of internet users who spent more than 2 hours a day $(D(218)=0.109, p=$ $0.000)$ and those who use internet for $1-2$ hours per day $(\mathrm{D}(101)=0.100, \mathrm{p}=0.002)$ are examined, ASTICT scores do not show normal distribution in all groups. In this case, Kruskal-Wallis test, a non-parametric test, was used to determine whether the attitudes of the prospective teacher candidates towards Information and Communication Technologies differ by the frequency of internet usage. The results of this test are given in Table 8 .

Table 8. Results of the Kruskal-Wallis Test applied to the "ASTICT" scores in terms of frequency of internet use of the teacher candidates

\begin{tabular}{ccccccc}
\hline & Groups & $\mathrm{N}$ & $\bar{x}_{\text {(rank) }}$ & $\chi^{2}$ & sd & $\mathrm{p}$ \\
\hline \multirow{3}{*}{ ASTICT } & Less than 1 hour per day & 17 & 142.38 & & & \\
& $1-2$ hours a day & 101 & 159.41 & 3.018 & 2 & .221 \\
& More than 2 hours a day & 218 & 174.75 & & & \\
\hline
\end{tabular}

When Table 8 is examined, it is seen that there is not a meaningful difference between the means of ASTICT scores of teacher candidates $\left(\chi^{2}=3.018 ; p>05\right)$ with regard to the frequency of internet use. Accordingly, the attitudes of prospective teacher candidates towards information and communication technologies do not differ by the frequency of internet use.

\subsection{Findings on Whether Teacher Candidates' Proficiency Perception Scores in Using Information and Communication Technologies Differ by Majors}

To determine whether the teacher candidates' proficiency perception scores in ICT usage differ by the majors, first "Kolmogorov-Smirnov Normality Test" was used to test whether the scores obtained from the scale are normally distributed in terms of the majors. The results are given in Table 9. 
Table 9. Normality of the distribution of teacher candidates" "PPSUICT" scores in terms of their majors

\begin{tabular}{clccc}
\hline \multirow{2}{*}{ Departments } & \multicolumn{3}{c}{ Kolmogorov-Smirnov } \\
\cline { 3 - 5 } & Science Education & .193 & 70 & .000 \\
& Mathematics Education & .133 & 41 & .066 \\
& Preschool Education & .143 & 44 & .024 \\
\multirow{5}{*}{ PPSUICT } & Psychological Counseling and Guidance & .053 & 54 & .200 \\
& Elementary Education & .186 & 38 & .002 \\
& Social Sciences Education & .077 & 42 & .200 \\
& TurkishLanguage Education & .090 & 47 & .200 \\
\hline
\end{tabular}

When the PPSUICT scores of the students in the Department of Science Teacher Education $(D(70)=0.193, p=$ $0.000)$, scores of the students in the Preschool Education Department $(D(44)=0.143, p=0.024)$ and those who are in Elementary Education Department $(\mathrm{D}(38)=0.186, \mathrm{p}=0,002)$ in Table 9.are examined, the PPSUICT scores do not show normal distribution in all groups. In this case, Kruskal-Wallis test, a nonparametric test, was used to determine whether teacher candidates' Proficiency perceptions of Information and Communication Technology Usage differ by the majors or not. The results for this test are given in Table 10.

Table 10. Results of the Kruskal-Wallis Test applied to "PPSUICT" scores of the teacher candidates in terms of their majors

\begin{tabular}{ccccccc}
\hline Groups & N & $\bar{x}_{\text {(rank) }}$ & $\chi^{2}$ & sd & p \\
\hline Science Education & 70 & 193.14 & & & \\
Mathematics Education & 41 & 170.10 & & & \\
PrSUICT & Psychological Counseling and Guidance & 54 & 156.51 & 9.626 & 6 & .141 \\
& Elementary Education & 38 & 177.12 & & & \\
& Social Sciences Education & 42 & 175.82 & & & \\
& Turkish Language Education. & 47 & 146.40 & & & \\
\hline
\end{tabular}

When Table 10 is examined, it is seen that there is no meaningful difference between the teacher candidates' score means of the PPSUICT scores $\left(\chi^{2}=9.626\right.$ and $\left.p>.05\right)$ in terms of their majors. Thus, the prospective teachers' competence perceptions regarding the use of information and communication technologies do not differ by the majors.

\subsection{Findings on Whether Teacher Candidates' Attitude Points Towards Information and Communication Technologies Differ by Their Majors}

To determine whether the teacher candidates' attitude scores towards ICT differ by the majors or not, first of all, "Kolmogorov-Smirnov Normality Test" was used to find whether the scores of the scale are normally distributed with regards to the majors to determine the appropriate statistical test to be used. The results are given in Table 11.

Table 11. Table of normality of "ASTICT" scores of teacher candidates in terms of majors

\begin{tabular}{llccc}
\hline \multirow{2}{*}{ Departments } & \multicolumn{3}{c}{ Kolmogorov-Smirnov } \\
\cline { 2 - 5 } & Science Education & Statistic & df & Sig. \\
\hline \multirow{6}{*}{ ASTICT } & .108 & 70 & .043 \\
& Mathematics Education & .123 & 41 & .123 \\
& Preschool Education & .203 & 44 & .000 \\
& Psychological Counseling and Guidance & .092 & 54 & .200 \\
& Elementary Education. & .195 & 38 & .200 \\
& Social Sciences Education & .188 & 42 & .001 \\
& Turkish Language Education & .096 & 47 & .200 \\
\hline
\end{tabular}


When ASTICT scores of the students in the Department of Science Education $(\mathrm{D}(70)=0,108, \mathrm{p}=0.043)$, in Preschool Education $(\mathrm{D}(44)=0.203, \mathrm{p}=0.000)$ and in Social Sciences $(\mathrm{D}(42)=0.188, \mathrm{p}=0.001)$ in Table 11. are examined, ASTICT scores of the students do not show normal distribution in all groups. In this case, the Kruskal-Wallis test, a non-parametric test, was used to determine whether the attitudes of the prospective teachers towards Information and Communication Technologies differ by their majors. The results of this test are given in Table 12 .

Table 12. Results of the Kruskal-Wallis test applied to "ASTICT" scores of the teacher candidates in terms of majors

\begin{tabular}{llllllll}
\hline \multirow{2}{*}{ Groups } & $\mathrm{N}$ & $\bar{x}_{\text {(rank) }}$ & $\chi^{2}$ & sd & $\mathrm{p}$ \\
& & & & & & \\
\hline \multirow{2}{*}{ ASTICT } & Science Education & 41 & 165.66 & & & \\
& Mathematics Education & 44 & 165.74 & & & \\
& Preschool Education & Psychological Counseling and Guidance & 54 & 157.92 & 5.104 & 6 & \multirow{2}{*}{.531} \\
& Elementary Education & 38 & 165.71 & & & \\
& Social Sciences Education & 42 & 198.67 & & & \\
& Turkish Language Education & 47 & 169.70 & & & \\
\hline
\end{tabular}

When Table 12 is examined, it is seen that there is not a meaningful difference between the teacher candidates' ASTICT score means $\left(\chi^{2}=5.104\right.$ and $\left.\mathrm{p}>.05\right)$ regarding majors. Hence, the attitudes of the teacher candidates towards information and communication technologies do not differ by their majors.

3.6 Findings on Whether Prospective Teachers' Perceptions of Proficiency in Using Information and Communication Technologies and Attitudes toward Information and Communication Technologies Differ by Computer Ownership

For determining whether the teacher candidates' perceptions of competence regarding ICT use and their attitudes towards ICT differ by computer ownership, "Kolmogorov-Smirnov Normality Test" to test whether the scores obtained from the scales is normally distributed in terms of the computer ownership. The results are given in Table 13.

Table 13. The table of normality of the teacher candidates" scores of "PPSUICT" and "ASTICT" in terms of computer ownership

\begin{tabular}{lcccc}
\hline & \multirow{2}{*}{ Computer Ownership } & \multicolumn{3}{c}{ Kolmogorov-Smirnov } \\
\cline { 3 - 5 } & & Statistic & df & Sig. \\
\hline PPSUICT & have & .103 & 273 & .000 \\
scores & have not & .088 & 63 & .200 \\
ASTICT & have & .100 & 273 & .000 \\
scores & have not & .085 & 63 & .200 \\
\hline
\end{tabular}

PPSUICT scores do not show normal distribution for all groups when the PPSUICT scores of those who own computers $(D(273)=0.103, \mathrm{p}=0.000)$ are examined in Table 13. In this case, one-way PERMANOVA test, a nonparametric test, was used to determine whether teacher candidates' differ by their computer ownership and their perceptions of proficiency in using Information and Communication Technologies and their attitudes towards Information and Communication Technologies. Descriptive values of PPSUICT and ASTICT scores of teacher candidates are shown in Table 14. One-way PERMANOVA results applied to PPSUICT and ASTICT scores regarding to computer ownership of teacher candidates are given in Table 15. 
Table 14. Descriptive values of teacher candidates' PPSUICT and ASTICT scores in terms of computer ownership

\begin{tabular}{cccccccc}
\hline \multirow{2}{*}{ Computer Ownership } & $\mathrm{N}$ & $x$ & $\mathrm{ss}$ & $\mathrm{Z}$ & $\mathrm{p}$ & $\mathrm{r}$ \\
\hline \multirow{2}{*}{ PPSUICT } & Have & 273 & 3.75 & .58 & -3.308 & 0.001 & -0.18 \\
& Do not have & 63 & 3.48 & .60 & & & \\
\hline \multirow{2}{*}{ ASTICT } & Have & 273 & 3.75 & .62 & -3.548 & 0.000 & -0.19 \\
& Do not have & 63 & 3.54 & .51 & & & \\
\hline
\end{tabular}

Table 15. One-way PERMANOVA results applied to PPSUICT and ASTICT scores in terms of computer ownership of teacher candidates

\begin{tabular}{lcccc}
\hline Independent Variable & Total Sum of Squares & Between Groups & $\mathrm{F}$ & $\mathrm{p}($ perm) \\
\hline Computer Ownership & 2.007 & 1.944 & 10.87 & 0.000 \\
\hline
\end{tabular}

When Table 15 is examined, it is seen that there are significant differences between the teacher candidates' perception of competence in using information and communication technologies and attitude scores on information and communication technologies in terms of computer ownership $(\mathrm{p}<.05)$. When Table 14 is examined, it can be said that this result is in favor of the computer owners; that is, the computer owners have a higher level of competence perception in using information and communication technologies and attitudes towards information and communication technologies than those who do not have computers.

According to the results of Mann Whitney U test to determine whether student candidates' PPSUICT and ASTICT scores differ in terms of their computer ownership in Table 14, there is a significant difference between both in PPSUICT score means $(Z=-3.08$ and $p=.001)(p<.05)$ and in ASTICT scores $(Z=-3.548$ and $p=, 000)(p<.05)$. Table 14 shows that when the mean scores of the PPSUICT and ASTICT and the standard deviation values of those who have computers and who do not have are compared, the mean score of the computer owners is higher than that of the others. On the other hand, the (r) value is used to determine the magnitude of the effect size of the computer ownership, independent variable, on PPSUICT and ASTICT scores. The obtained " $r$ " value is interpreted based on "d" index of Cohen (1988), which is one of the effect size indices. In this case, when the " $r$ " values obtained regarding computer ownership variables are taken into consideration $(r=-0.18$ for PPSUICT score means and $r=$ -0.19 for ASTICT score means), it can be said that the variable of computer ownership has a weak influence on teacher candidates' perceptions of competence in using information and communication technologies and their attitudes towards information and communication technologies.

\section{Discussion and Conclusion}

According to the findings of the study, teacher candidates' proficiency perceptions of using ICT do not show any significant difference in terms of their majors and the frequency of internet use. While the proficiency perceptions of the candidates in using ICT in terms of gender do not show a meaningful difference, their attitudes towards ICT show a meaningful difference in favor of men. In terms of computer ownership, teacher candidates differ significantly in favor of those who possess computers in both their perceptions of competence in using ICT and their attitudes towards ICT. Teacher candidates who do not have computers are found to have lower proficiency perceptions in using ICT and attitudes towards ICT than those who own computers. As a result, computer ownership appears as a variable that influences teacher candidates' proficiency perceptions and attitudes.

Today, computers are the basis of information and communication technologies used in education. Distance education, computer-aided instruction, educational software, video conferences, interactive smart boards, etc. are based on computers and computer operating systems. For this reason, it is very important for teacher candidates to acquire competencies related to computer use in teacher education. Therefore, the educational environments such as classrooms, laboratories, libraries should be robust and well-equipped. It is necessary to establish a technology infrastructure that enables the teacher candidates who cannot have personal computer to use the computer easily. In a survey conducted with 140 teacher candidates by Yelken, Çelikkaleli, and Çapri (2007), the candidates were asked how education faculty should be equipped. A significant number of the teacher candidates stated that the classes should have adequate technological equipment. If teacher candidates recognize and use these technologies in faculties equipped with information and communication technologies, receive qualified training for the use of these technologies, are encouraged to use these technologies in their pre-service teaching experience and given the opportunity to implement ICT, their perceptions of competence in using ICT and attitudes towards ICT will also develop positively. Therefore, while trying to improve the infrastructure of information and communication technologies in primary, secondary and high schools, it is necessary to develop technological infrastructure of the 
Education Faculties where prospective teachers are trained.

Göktaş, Z. Yıldırım, and S. Yıldırım (2008) conducted a survey of which study group consists of 63 Deans of the Faculty of Education to establish the status of information and communication technologies in education faculties in Turkey. Data were obtained through questionnaires in this survey. As a result of the research, the number of students per computer was 81 and above in 9 education faculties (17.6\%). In 11 of the faculties, this range was found to be between 1-20 (21.6\%), while the mean number of students per computer was found as 46 in 51 of the faculties. $35.3 \%$ of the deans stated that ICT is used sufficiently and $58.8 \%$ asserted it is used partially in the faculties. It has been determined that $66.7 \%$ of the education faculties do not have any in-service training for academic staff on ICT. While $80.4 \%$ of the computer laboratories are open to the use of students during off-hours in working hours (08:30-17:00), only 18 (35.3\%) of the education faculties allow students to use their laboratories after hours.

When the findings of the research are examined, it is seen that the infrastructure of information and communication technologies, especially computers, needs to be improved in Education Faculties. However, further research is needed to reveal the present state of the Education Faculties in information and communication technologies. It is necessary for our universities to improve ICT infrastructures by determining the current situation of Education Faculties with regard to ICT institutionally and their needs in this area. They need to establish the objectives and programs of ICT for effective use by teacher candidates and instructors, and it is also necessary to monitor and evaluate them. If the desired objectives are reached in these areas, teacher candidates' proficiency perceptions in using ICT and their attitudes towards ICT should be examined again through further studies.

\section{References}

Arseven, A. (2016). Self efficacy: Analysis of a concept. Turkish Studies, 11(19), 63-80. https://doi.org/10.7827/TurkishStudies.10001

Avrupa Komisyonu. (2013). Survey of Schools: ICT in education final report. European Commission.

Erdemir, N., Bakırc1, H., \& Eyduran, E. (2009). Determination of self-confidence of teacher candidates using technology in education. Turkish Journal of Science Education, 6(3), 99-108.

Fanai, L., \& Chhangte, R. (2016). A Study of the attitude of the secondary school teachers towards ICT with respect to teaching experience and professional qualification. International Journal of Engineering Science and Computing, 6(8), 2878-2880.

Ghavifekr, S., \& Rosdy, W. A. W. (2015). Teaching and learning with technology: effectiveness of ICT integration in schools. International Journal of Research in Education and Science (IJRES), 1(2), 175-191. https://doi.org/10.21890/ijres.23596

Giles, R. M., \& Kent, A. M. (2016). An investigation of preservice teachers' self-efficacy for teaching with technology. Asian Education Studies, 1(1), 32-40. https://doi.org/10.20849/aes.v1i1.19

Göktaş, Y., Yıldırım, Z., \& Yıldırım, S. (2008). Information and communication technologies in the faculties of education: deans' opinions. Education and Science, 33(149), 30-50.

Günbatar, M. S. (2014). Developing an attitude scale for Information and Communication Technologies. Ahi Evran University Kırşehir Education Faculty Journal, 15(1), 121-135.

Kalkan, A. (2011). The effect of personal attitude, subjective norm and perceived behavior control on entrepreneurial intention: an application on university students. Süleyman Demirel University Institute of Social Sciences Journal, 2(14), 189-206.

Kılıç, S. (2014). Effect size with statistical expression. Journal of Mood Disorders, 4(1), 44-46. https://doi.org/10.5455/jmood.20140228012836

Kubiatko, M. (2010). Czech university students' attitudes towards ICT used in science education. Journal of Technology and Education, 2(3), 20-25. https://doi.org/10.5507/jtie.2010.042

Mai, M. Y. (2015). Science teachers' attitudes towards using ICT and mobile learning Technologies in Malaysian $\begin{array}{lllll}\text { schools. European Journal of Interdisciplinary Studies, } & 3(1), & \text { 187-196. }\end{array}$ https://doi.org/10.26417/ejis.v3i1.p187-196

MEB. (2006). Tedp Basic Education Support Project “Teacher Training Component it: General Qualifications of Teaching Profession. Ministry of National Education Journal of Publications, 69 (2590), 1491-1540.

MEB. (2017). General Qualifications of Teaching Profession. Retrieved from 
http://oygm.meb.gov.tr/meb_iys_dosyalar/2017_12/11115355_YYRETMENLYK_MESLEYY_GENEL_Y ETERLYKLERY.pdf on 13.07.2018

MEB. (2018). FATIH project in education. Retrieved from http://fatihprojesi.meb.gov.tr on 01.07.2018

Pasin, Ö., Ankaral, H., Cangür, Ş., \& Sungur, M. A. (2016). Nonparametric multivariate analysis of variance and an application in the field of health. Journal of Information Technologies, 9(1), 13-20.

Pelgrum, W., \& Law, N. (2003). ICT in education around the world: trends, problems and prospects. UNESCO-IIEP, Paris.

Polat, Ç., \& Odabaş, C. (2008). The key to lifelong learning in the information society: Information literacy. İn Globalization, Democratization and Turkey International Symposium Proceedings. 27-30 Mart, Antalya.

Şad, S. N., \& Nalçacı, Ö. İ. (2015). Perceptions of teacher candidates' ability to use information and communication technologies in education. Mersin University Faculty of Education Journal, 11(1), 177-197.

Sanyal, B. C. (2001). New functions of higher education and ICT to achieve education for all. Paper prepared for the Expert Roundtable on University and Technology-for Literacy and Education Partnership in Developing Countries, International Institute for Educational Planning, UNESCO, September 10 to 12, Paris.

Sayginer, Ş. (2016). Examining the relationship between the computer teachers' perceptions of computer proficiency levels and technology perceptions. Mustafa Kemal University Journal of Institute of Social Sciences, 13(34), 298-312.

Scherer, R., \& Siddiq, F. (2015). Revisiting teachers' computer self-efficacy: a differentiated view on gender differnces. Computers and Human Behavior, 53, 48-57. https://doi.org/10.1016/j.chb.2015.06.038

Tuti, S. (2005). Use of Information Technologies in Education, Performance Indicators, Evaluation of Student Opinions and Self-Efficacy Perceptions (Unpublished master thesis). Ankara: Hacettepe Üniversitesi, Fen Bilimleri Enstitüsü.

Umar, İ. N., \& Jalil, N. A. (2012). ICT skills, practices and barriers of its use among secondary school students. Procedia-Social and Behavioral Sciences 46, 5672-5676. https://doi.org/10.1016/j.sbspro.2012.06.494

UNESCO. (2002). Information and communication technologies in teacher education, A planning guide. Paris: UNESCO.

Yelken, T. Y., Çelikkaleli, Ö., \& Çapri, B. (2007). The views of prospective teachers on the determination of the quality standards of the Faculty of Education: The case of Mersin University. Mersin University Faculty of Education Journal, 3(2), 191-215.

Yilmaz, M. (2016). Evaluation of Computer Competencies and Technology Attitudes Towards Primary School Teachers' Use of Technology in Education (Master thesis, Mersin Üniversitesi, Eğitim Bilimleri Enstitüsü, Mersin).

Yirci, R., \& Aydoğar, N. (2017). To examine the attitudes of university students towards information and communication technologies in terms of some variables. Ulakbilge, 5(18), 2175-2200. https://doi.org/10.7816/ulakbilge-05-18-13

\section{Copyrights}

Copyright for this article is retained by the author(s), with first publication rights granted to the journal.

This is an open-access article distributed under the terms and conditions of the Creative Commons Attribution license (http://creativecommons.org/licenses/by/4.0/). 